\title{
CULTIVATION OF THE EXOERYTHROCYTIC STAGE OF PLASMODIUM BERGHEI IN PRIMARY CULTURES OF MOUSE HEPATOCYTES AND CONTINUOUS MOUSE CELL LINES
}

\author{
GARY W. LONG, SIMON LEATH, RICHARD SCHUMAN, MICHAEL R. HOLLINGDALE, \\ W. RIPLEY BALLOU ${ }^{1}$, BETTY KIM LEE SIM, AND STEPHEN L. HOFFMAN \\ Malaria Program, Infectious Diseases Department, Naval Medical Research Institute, Bethesda, Maryland \\ 20814 (G. W. L., S. L. H.); Biomedical Research Institute, 12111 Parklawn Drive, Rockville, \\ Maryland 20852 (S. L., M. R. H.); Antibody Resources, 649 D Los Strand Lane, Rockville, \\ Maryland 20850 (R. S.); and Department of Immunology, Division of Communicable \\ Diseases and Immunology, Walter Reed Army Institute of Research, \\ Washington, DC 20307 (W. R. B.. B. K. L. S.) \\ (Received 27 December 1988; accepted 16 May 1989)
}

\begin{abstract}
SUMMARY
Plasmodium berghei exoerythrocytic (EE) stages have been cultured in vitro in human continuous cell lines and primary cultures of both human and rat hepatocytes. Although the predominant experimental model of irradiated sporozoite-induced protective immunity is the mouse, $P$. berghei has not been cultivated in primary mouse hepatocytes or in continuous mouse lines. Because of this, target cells are not available for determining if these immunized mice produce cytotoxic $T$ lymphocytes (CTLs) that recognize $P$. berghei antigens expressed on hepatocytes in the context of class I major histocompatability (MHC) antigens. We report the development of methods for cultivating the (EE) stage of $P$. berghei in murine hepatocytes and in two cell lines derived from the livers of BALB/c mice; one line produced from a primary hepatocyte culture and the other produced by fusion of mouse hepatocytes with a continuous rat liver line. Mature parasites were detected by microscopy and by DNA probe in both cell lines, each of which supported complete development of $P$. berghei liver stages and production of infectious merozoites. Since class I MHC antigens are present on the surface of primary hepatocytes and the mouse $X$ rat hybrid line, these cells can be used to detect cytotoxic $T$ cells against liver stage parasites.
\end{abstract}

Key words: malaria; Plasmodium berghei; exoerythrocytic; hepatocyte; primary culture; continuous culture.

Mice immunized with irradiated Plasmodium berghei sporozoites are solidly protected against subsequent sporozoite challenge $(4,12)$. Immunized mice produce antibudies to the circumsporozoite (CS) protein of $P$. berghei and such antibodies may protect against moderate sporozoite challenge $(2,8)$. Sporozoite-induced immunity does not protect against blood-stage infection (11) and may be directed against either sporozoites or exoerythrocytic (EE) stages of the parasites in the liver. Protection against large sporozoite challenge can be achieved independent of antibodies (1) and is probably dependent on a T-cell-mediated response $(2,15,18)$.

Sporozoites rapidly invade hepatocytes after entry into the host and develop within these cells. A possible mechanism for cell-mediated protective immunity is the recognition of malaria antigens by cytotoxic $T$ lymphocytes (CTLs) on the hepatocyte surface. CTLs recognize

\footnotetext{
${ }^{1}$ Present address: Univax Corporation, 12111 Parklawn Drive, Rockville, MD 20852.
}

foreign antigens only when expressed in the context of class I major histocompatability (MHC) antigens. Cells expressing MHC antigens and capable of maintaining parasite growth are therefore required for demonstration of antigen specific, class I restricted destruction of EE stages of malaria. Research in this area has been hindered by the lack of a suitable in vitro model. Exoerythrocytic stages of $P$. berghei have been cultured in a human embryonic lung line (W138) and a human hepatoma cell line (HepG2) $(5,7)$, in primary cultures of rat hepatocytes infected in vivo (3), and in rat hepatocytes (14). Sporozoites invade and develop in these cells to mature EE stages. However, due to the class I restriction, these systems cannot be used to study mouse CTL responses against EE-stage antigens. Research on the cultivation of rodent hepatocytes has concentrated on primary cultures of rat cells. Little work has been carried out on mouse liver cells, and their maintenance in culture has proven to be more difficult. We report the development of a system for culturing mouse hepatocytes, and the production of two continuous mouse liver 
cell lines, that support the invasion of $P$. berghei sporozoites and their development to the mature liver stage.

\section{Materials AND Methods}

Culture media. Primary hepatocyte cultures were grown in Williams' medium E (WME) with $10 \%$ fetal bovine serum (FBS), $25 \mathrm{mM}$ HEPES, $100 \mathrm{U} / \mathrm{ml}$ penicillin, $100 \mu \mathrm{g} / \mathrm{ml}$ streptomycin, and $5 \mu \mathrm{g} / \mathrm{ml}$ Fungizone (Flow Laboratories Inc., McLean, VA), supplemented with 10 $\mu \mathrm{g} / \mathrm{ml}$ insulin, $10 \mu \mathrm{g} / \mathrm{ml}$ transferrin, $10 \mathrm{ng} / \mathrm{ml}$ selenous acid (ITS Solution; Collaborative Research Inc., Lexington, MA), $1 \mu M$ dexamethasone (Collaborative Research), $5 \mathrm{ng} / \mathrm{ml}$ epidermal growth factor, $0.1 \mu M$ glucagon, 10 $\mu \mathrm{U} / \mathrm{ml}$ somatotropin, and $20 \mathrm{mU} / \mathrm{ml}$ prolactin /Sigma Chemical Co., St. Louis, MO).

Hepatocyte isolation and culture. Hepatocytes were isolated from $\mathrm{C} 57 \mathrm{Bl} / 6$ or $\mathrm{BALB} / \mathrm{c}$ mice by the method of Klaunig et al. (9). The livers were perfused in situ by cannulating the thoracic inferior vena cava. The hepatic portal vein was severed and the perfusate allowed to run to waste. Fifty milliliter of calcium free Hank's balanced salt solution (HBSS; Flow Laboratories) plus $0.5 \mathrm{mM}$

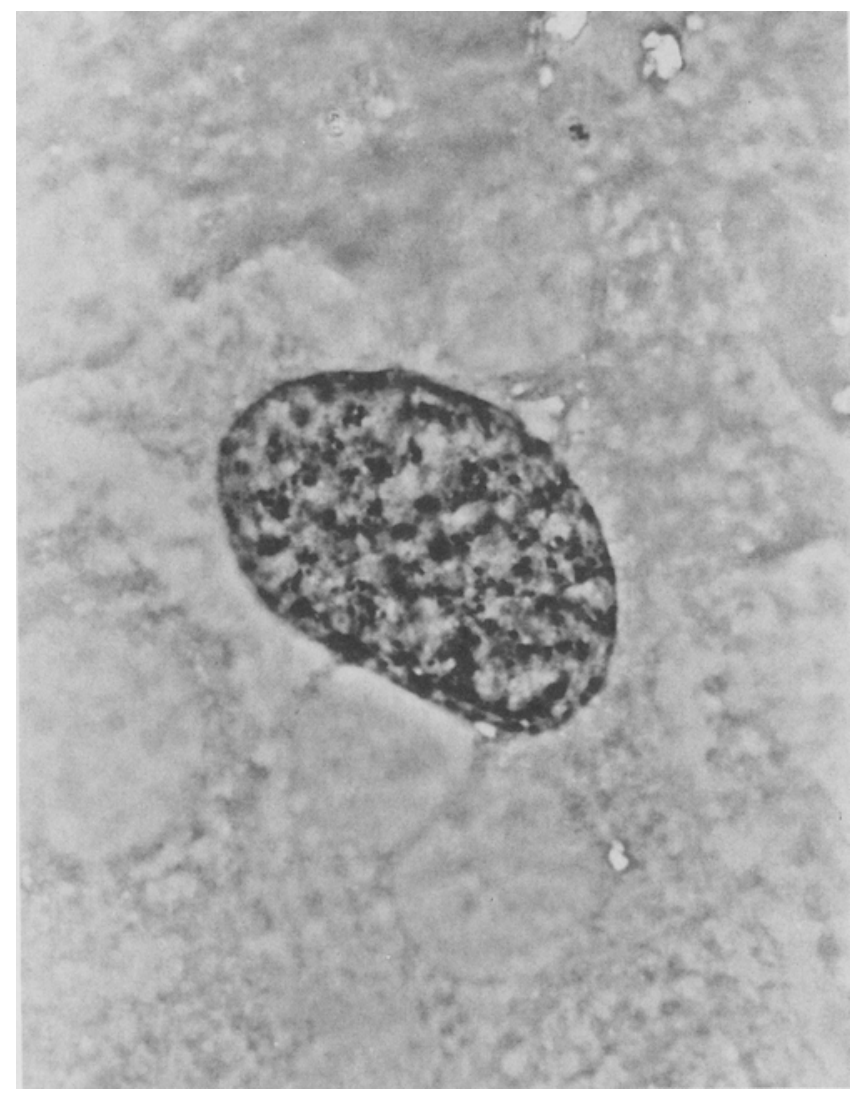

FIG. 1. Plasmodium berghei exoerythrocytic schizont in primary mouse hepatocyte $48 \mathrm{~h}$ postinfection. $\times 952$. Immunoperoxidase staining with a monoclonal antibody [NBS] 13:28:1)] raised against irradiated $P$. berghei sporozoites which recognizes DPAPPNAN, the major octapeptide repeat on the $P$. berghei $\mathrm{CS}$ protein.

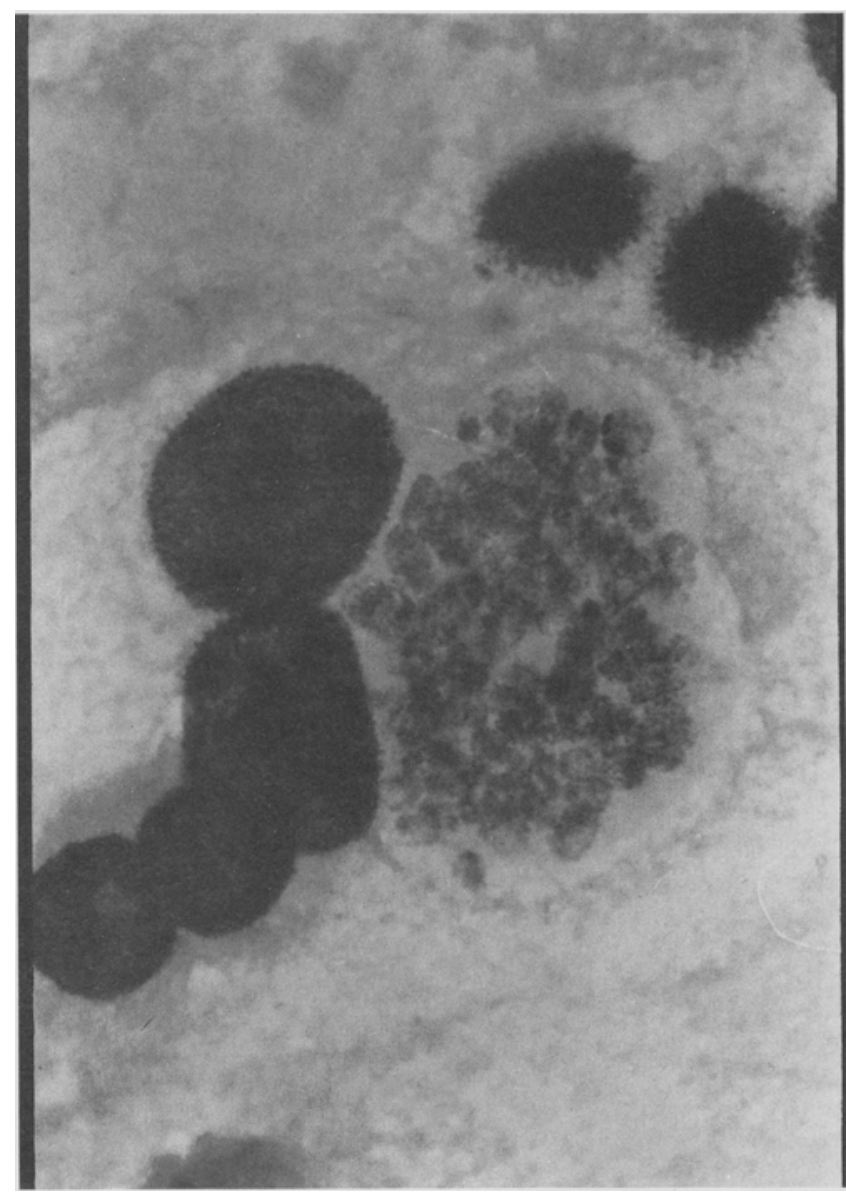

FIG, 2. Giemsa-stained EE stage schizont $48 \mathrm{~h}$ after in vitro infection of primary hepatocyte culture. $\times 1050$.

EGTA followed by $100 \mathrm{ml} \quad 0.05 \%$ collagenase (Sigma Chemical Co.) in HBSS containing $5 \mathrm{~m} M$ calcium chloride were perfused at a rate of $10 \mathrm{ml} / \mathrm{min}$. All solutions were maintained at $37^{\circ} \mathrm{C}$ and continuously gassed with a mixture of $95 \% \quad \mathrm{O}_{2}: 5 \% \quad \mathrm{CO}_{2}$. The liver was removed and the cells were released into cold, $2.5 \%(\mathrm{wt} / \mathrm{vol})$ fatty acid-free bovine serum albumin (BSA) (Sigma Chemical Co.) in HBSS by teasing, and further separated by pipetting several times with a large-tip pipette. The suspension was filtered through nylon mesh and centrifuged for $5 \mathrm{~min}$ at $50 \times \mathrm{g}$. The cells were resuspended in culture media and plated at a density of 1 $\times 10^{5} \mathrm{cells} / \mathrm{cm}^{2}$ on $12-\mathrm{mm}$ glass cover slips coated with mouse-tail collagen. The culture media was changed $3 \mathrm{~h}$ after plating to remove nonattached cells and every $24 \mathrm{~h}$ thereafter. Approximately 60000 cells remained per cover slip $48 \mathrm{~h}$ after plating.

\section{Production of Cell Lines}

Mouse hepatocyte line. Hepatocytes were collected from the livers of $\mathrm{BALB} / \mathrm{c}$ mice as above. Cells were cultured in WME (Flow Laboratories) supplemented with $10 \% \mathrm{FBS}^{1} 10^{-7} \mathrm{M}$ dexamethasone, and $10 \mu \mathrm{g} / \mathrm{ml}$ insulin 
TABLE 1

\section{NUMBER OF EXOERYTHROCYTIC STAGE SCHIZONTS IN PRIMARY MURINE HEPATOCYTES 48 H AF'TER INFECTION WITH 40000 SPOROZOITES ${ }^{a}$}

\begin{tabular}{lcccc}
\hline $\begin{array}{l}\text { Experiment } \\
\text { Number }\end{array}$ & $\begin{array}{c}\text { Number of 48-H } \\
\text { Schizonts }^{a}\end{array}$ & $\begin{array}{c}\text { Number of } \\
\text { Sporozoites } \\
\text { Added, } \times 10^{3}\end{array}$ & $\begin{array}{c}\text { Percent } \\
\text { Sporozoites } \\
\text { that Invade } \\
\text { and Develop }\end{array}$ & $\begin{array}{c}\text { Percent } \\
\text { Hepatocytes } \\
\text { Infected }^{b}\end{array}$ \\
\hline 1 & 145 & 37.5 & 0.39 & 0.24 \\
2 & 176 & 40 & 0.44 & 0.29 \\
3 & 143 & 40 & 0.36 & 0.24 \\
4 & 162 & 35 & 0.53 & 0.27 \\
Mean & 157 & & 0.41 & 0.26 \\
\hline
\end{tabular}

${ }^{a}$ Average of two cover slips. Parasites quantitated by direct counting of immunoperoxidase stained liver stages.

${ }^{b}$ Based on an estimated 60000 hepatocytes per cover slip.

(Collaborative Research) for 2 wk. After 2 wk, several colonies of cells were observed on the plates. These were subcultured and passaged in WME with $10 \%$ FBS.

Mouse/rat hybrid line. Production of the BALB/c hepatocyte $X$ rat hybrid cell line (designated $E 2$ ) was previously described (16). Briefly, the BALB/c hepatocytes were fused to a malignant rat liver cell line (FRL; provided by Dr. M. K. Wilson, FCRF, Frederick, MD) and hybrids selected by addition of HAT (hypoxanthine, $1 \times 10^{-4} \mathrm{M}$, aminopterin, $4 \times 10^{-7} \mathrm{M}$; thymidine, $1.6 \times 10^{-7}$ $M$; Flow Laboratories).

Infection of cells. The NK 65 strain of $P$. berghei was grown in Anopheles stephensi mosquitoes. Salivary glands were dissected into Medium 199 containing $10 \%$ heat inactivated mouse serum, disrupted in a tissue grinder, and counted. Sporozoites suspended in $200 \mu \mathrm{l}$ of media were added to cover slips in shell vials and incubated for $2 \mathrm{~h}$. Fresh media containing $200 \mathrm{U} / \mathrm{ml}$ penicillin and $200 \mu \mathrm{g} / \mathrm{ml}$ streptomycin was added to the cultures and changed twice daily thereafter. In some cases, monolayers were infected by centrifugation. Sporozoites were added to cells growing on cover slips in shell vials. These were capped and centrifuged at room temperature $(1000 \times g$ for $5 \mathrm{~min})$. The cultures were incubated for $1 \mathrm{~h}$ at $37^{\circ} \mathrm{C}$, at which time the cultures were washed and the media replaced as above.

\section{Immune Staining}

Infected cell monolayers were fixed with methanol, and parasites were visualized by immunoperoxidase (6) with a monoclonal antibody against the sporozoite CS protein [NBS1 (previously designated 3:28.1) Charoenovit, Y. personal communication]. Immune staining for flow cytometry was performed following standard methods. Class I MHC antigens were detected by incubation with monoclonal antibody to $\mathrm{H} \cdot 2 \mathrm{D}^{d}$ (ATCC HB-75, HB-102) (13), and a rat monolconal to $\mathrm{H}-2$ monotypic antigen (M1/42, Hybritech, Inc. San Diego, CA) (17) followed by treatment with fluorescein-labeled goat antimouse Ig (Becton Dickinson and Co., Mountain View, CA) or goat antirat Ig (Boehringer Mannheim Biochemicals, Indianapolis, IN). Samples were measured on a FACS II (Becton Dickinson and Co.) coupled to a PDP 11/40 computer (Digital Equipment Corp., Maynard, CA). Control samples were treated with second antibody alone. Intracellular albumin was detected by methanol fixation and permeabilization of the suspended cells (10) before staining with rabbit antimouse albumin (Cooper Biomedical, Malvern, PA).

\section{Detection of Parasite DNA}

A highly repeated fragment of $P$. berghei DNA (pPB3; Sim, unpublished) was used as a probe to detect parasite DNA. $P$ berghei infected, and uninfected cell monolayers growing on cover slips, were incubated for $24 \mathrm{~h}$ at $37^{\circ} \mathrm{C}$ inverted onto nitrocellulose filters, backed by Whatman 3MM paper soaked with $0.5 M$ EDTA, pH 9.5, 1.0\% sarcosyl and $2 \mathrm{mg} / \mathrm{ml}$ proteinase $K$ (Boehringer Mann. heim). The cover slips were removed and the nitrocellulose filters were air dried. Retained DNA was denatured by placing filters onto puddles of $0.5 M \mathrm{NaOH}$ (twice for 2 min), and then neutralized with $1 M$ tris (pH 7.4) (twice for $5 \mathrm{~min}$ ), and $1.5 \mathrm{M} \mathrm{NaCl}, 0.5 \mathrm{M}$ tris (pH 7.4) (twice for 5 min). The specimens were air dried and baked for $2 \mathrm{~h}$ at $80^{\circ} \mathrm{C}$ in vacuo and then prehybridized for $2 \mathrm{~h}$ at $42^{\circ} \mathrm{C}$ in $10 \times$ Denhardt's $(50 \times$ Denhardt's: $1.0 \%$ Ficoll, $1.0 \%$ BSA, $1.0 \%$ polyvinylpyrrolidone), $2.5 \times$ SSC (sodium chloride, sodium citrate) $(20 \times$ SSC: $3.0 M \mathrm{NaCl}, 0.3 M \mathrm{NaCitrate}, \mathrm{pH}$ $7.0 \%, 100 \mu \mathrm{g} / \mathrm{ml}$ salmon sperm DNA, $50 \%$ formamide, and $0.1 \%$ sodium dodecyl sulfoxide (SDS). The filters were then hybridized for $12 \mathrm{~h}$ with ${ }^{32} \mathrm{P}$-labeled $\mathrm{pPb3}$ and washed 3 times $30 \mathrm{~min}$ at $50^{\circ} \mathrm{C} \quad(0.1 \times \mathrm{SSC}, \quad 0.5 \% \quad \mathrm{SDS})$ before autoradiography.

\section{RESULTS}

Exoerythrocytic stage development in primary hepatocytes. Primary hepatocyte suspensions of approximately

\section{TABLE 2}

\section{PLASMODIUM BERGHEI SCHIZONT DEVELOPMENT AND LIVER MEROZOITE INFECTIVITY IN CONTINUOUS BALB/C CELL LINES}

\begin{tabular}{lcccc}
\hline Cell Line & $\begin{array}{c}\text { Hours } \\
\text { Postinfection }\end{array}$ & $\begin{array}{c}\text { Number of } \\
\text { Schizonts }\end{array}$ & $\begin{array}{c}\text { Size. } \\
\mu .4 \pm S E\end{array}$ & $\begin{array}{c}\text { Merozoite } \\
\text { Infectivity }^{b}\end{array}$ \\
\hline BALB/c Line & 28 & 199.0 & $10.3 \pm 0.3$ & ND \\
& 42 & 149.5 & & $0 / 3$ \\
& 45 & 142.0 & $12.9 \pm 0.6$ & $0 / 3$ \\
& 47 & 114.5 & $12.8 \pm 0.6$ & $2 / 3$ \\
& 49 & 50.5 & & ND
\end{tabular}

Mouse $\times$ Rat

Hybrid

$\begin{array}{rrrr}28 & 31.5 & 10.9 \pm 1.1 & \text { ND } \\ 42 & 25.5 & & 0 / 3 \\ 45 & 16.5 & 15.1 \pm 1.0 & 0 / 3 \\ 47 & 10.5 & 15.1 \pm 0.8 & 1 / 3 \\ 49 & 6.0 & & \text { ND }\end{array}$

"Cells grown on 12-mm cover slips and infected by centrifugation of 50000 sporozoites. Number is the average of two cover slips determined by immunoperoxidase staining.

"Mice each received i.v. injection of supernatants from four cultures. 
$80 \%$ viability (trypan blue exclusion) were produced using the described procedure. Exposure of the monolayers to $P$. berghei sporozoites resulted in the formation at $48 \mathrm{~h}$ of schizonts averaging $30 \mu \mathrm{m}$ in diameter. Liver stages were positive by immunoperoxidase using a monoclonal antibody to the CS protein (Fig. 1) and with antisera produced against blood-stage parasites by repeated inoculation of mice with infected blood. Giemsa-stained parasites (Fig. 2) seemed to be mature by $48 \mathrm{~h}$ and contained numerous merozoites. Injection of supernatants from these cultures into mice failed to produce blood-stage infections, suggesting that complete development of schizonts with rupture and release of infectious merozoites did not occur.

The results of four experiments using hepatocytes cultured from $\mathrm{C} 57 \mathrm{Bl} / 6$ mice are shown in Table 1 . We added 40000 sporozoites per cover slip $3 \mathrm{~h}$ after plating of the cells, and consistently observed by immunoperoxidase staining approximately 150 liver schizonts per cover slip representing 0.4 to $0.5 \%$ of the sporozoites added; an infection rate of $0.25 \%$ of the 60000 hepatocytes per cover slip. Similar results were obtained using hepatocytes cultured from BALB/c mice. Attempts to increase the number of schizonts by addition of larger numbers of sporozoites have thus far been unsuccessful.
Infection of cell lines. One of the spontaneously transformed BALB/c cell lines, and the mouse $X$ rat hybrid line, supported invasion and development of $P$. berghei sporozoites to late liver schizonts in vitro (Table 2). Consistent results with these lines were best obtained by centrifuging the sporozoites onto the cell layers. This was not the case for primary hepatocytes, which did not tolerate centrifugation. The diameter of schizonts produced in the cell lines seemed smaller on fixed slides than those produced in the hepatocyte cultures (approximately 13 to $15 \mu M$ in diameter compared to $30 \mu M$ in primary cultures). Rupture of the schizonts and release of infectious merozoites occurred between 45 and $47 \mathrm{~h}$ after infection of the cultures. Two of three BALB/c mice that received intravenous injections of $47-\mathrm{h}$ culture supernatants from the spontaneously transformed line, and one of three from the mouse/rat hybrid line, developed blood stage infections (Table 2 ).

Characterization of cell lines. We tested both lines for murine MHC antigens by flow cytometry to determine if either cell line could be used in an assay to assess class I MHC restricted killing of infected cells by immune lymphocytes. Both lines were tested for murine class I antigens using monoclonal antibodies to $\mathrm{H}-2 \mathrm{D}^{d}$ (Fig. $3 \mathrm{~A}$, $B)$ and to H-2 monotypic antigen. The mouse $X$ rat hybrid
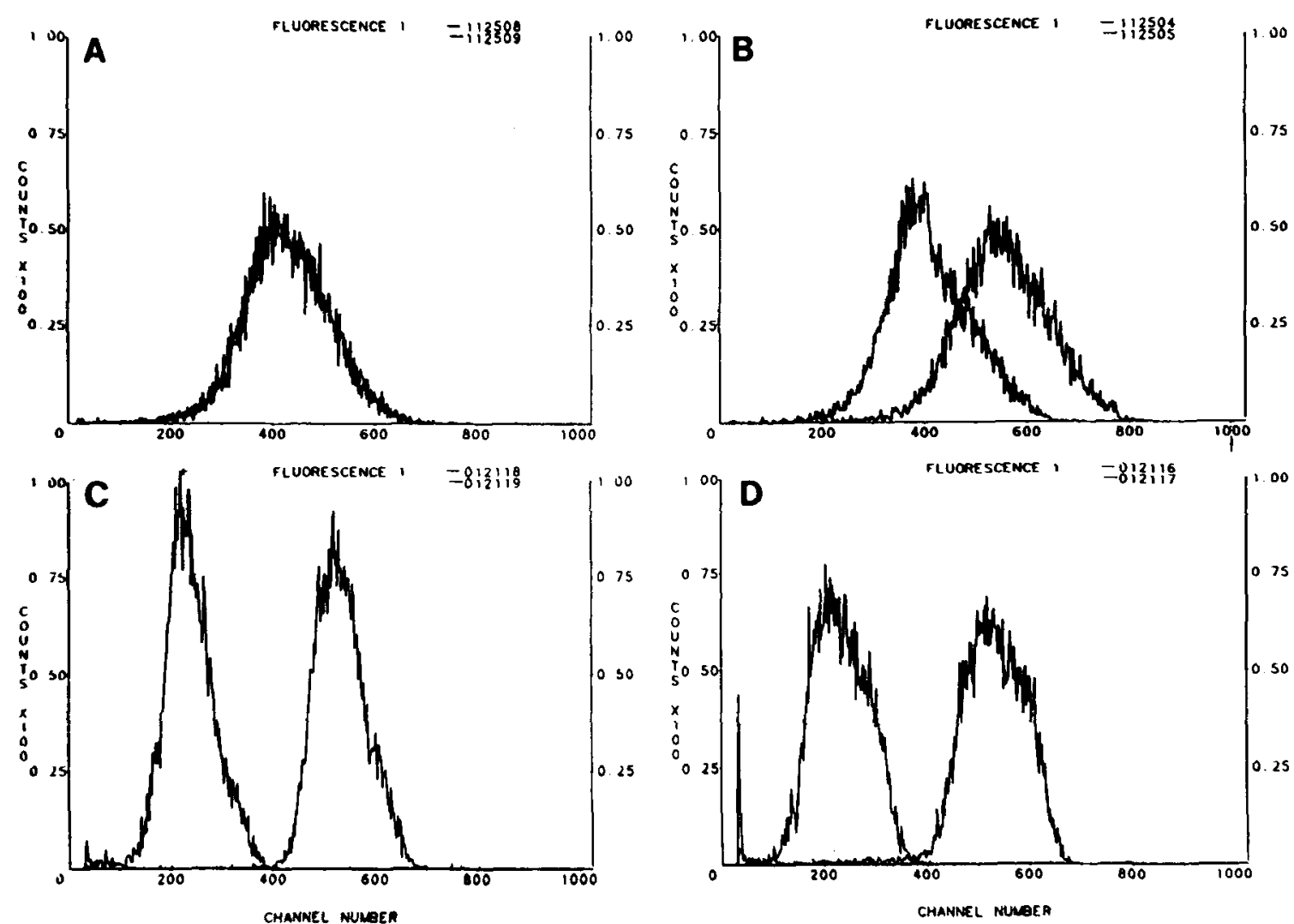

FIG. 3. Flow cytometry analysis of surface class I MHC antigens of continuous cell lines derived from livers of BALB/c mice. $A$, the spontaneously transformed BALB/c line has been treated with the monoclonal (ATCC HB-75) against $\mathrm{H}-2 \mathrm{D}^{d} ; B$, is the mouse $\times$ rat hybrid treated with the same monoclonal. Graphs show results plotted along with negative control (fluorescein conjugate only). Continuous BALB/c line $(C)$ and mouse-rat hybrid line $(D)$ were also tested for intracellular albumin. Graphs plotted with negative control. 
line was positive for surface $\mathrm{H}-2 \mathrm{D}^{d}(\mathrm{Fig} .3 \mathrm{~B}$ ) and also for monotypic antigen (not shown). The parent rat line was negative. The BALB/c hepatocyte line was negative with antibody to $\mathrm{H}-2 \mathrm{D}^{d}$ (Fig. $3 A$ ) and with $\mathrm{H}-2$ monotypic antibody (not shown). We also tested the lines for the production of albumin, which is a hepatocyte-specific function. Both lines were positive for intracellular mouse albumin by flow cytometry (Fig. $3 C, D$ ).

Assessment of infection by DNA probe. Measuring rates of infection by light microscopy is laborious and often difficult. We therefore attempted to assess the development of parasite-specific DNA by hybridization. Using the $P$. berghei specific DNA probe $(\mathrm{pPb} 3)$ we were

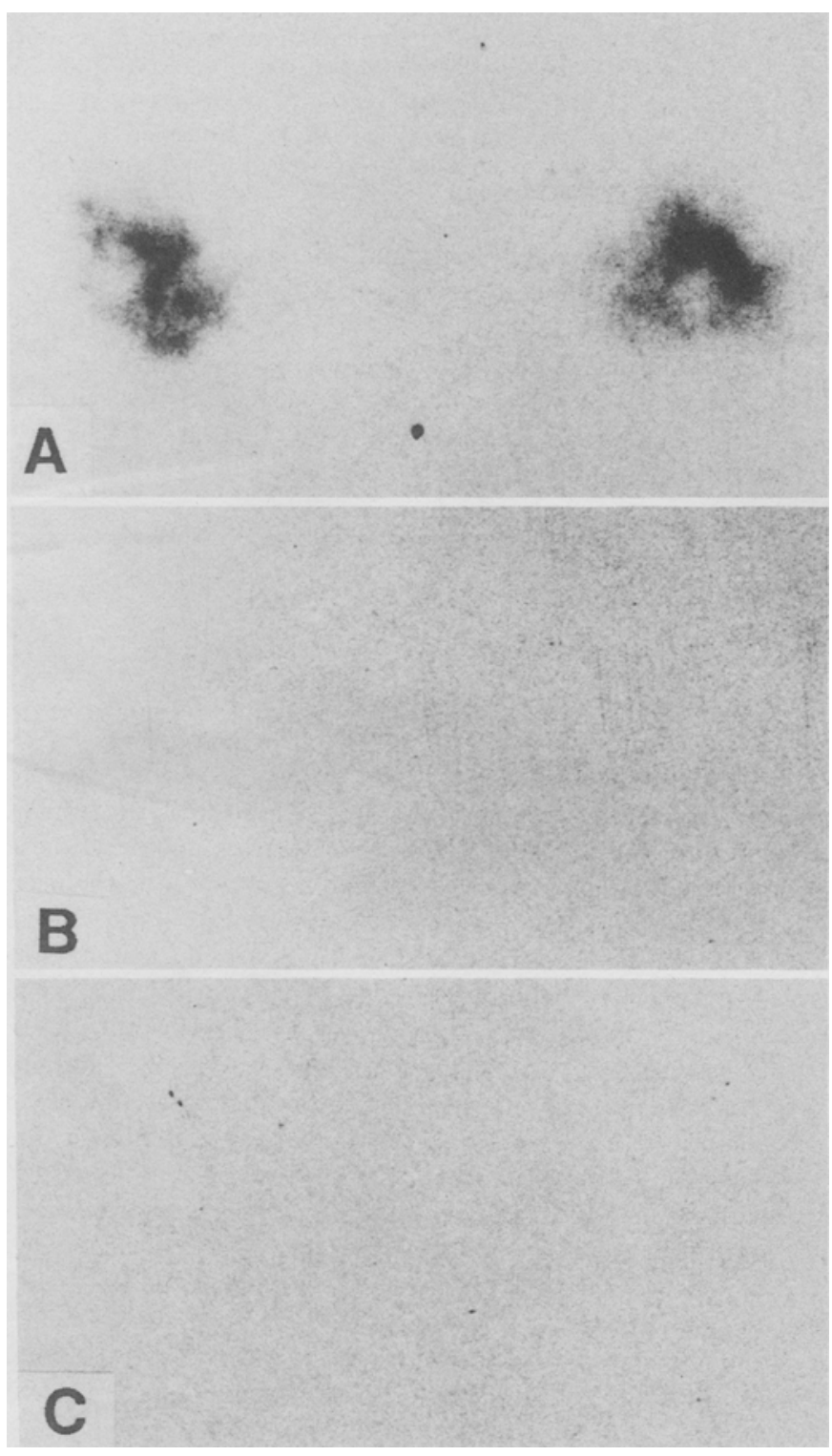

FIG. 4. Autoradiograph of infected monolayers of BALB/c cell line following reaction with a $P$, berghei DNA probe. Cultures were analyzed $40 \mathrm{~h}$ after infection with $P$. berghei sporozoites $(A)$; and 20 hours after infection $(B)$. Uniníected cultures are shown in $C$. able to demonstrate the development of parasite-specific DNA during the cycle of infection and development (Fig. 4).

\section{DisCuSSION}

We have developed a method to culture murine hepatocytes and have infected them with $P$. berghei sporozoites. The hepatocytes support growth of the parasites and the production of $\mathbf{E E}$ schizonts. Schizonts average $30 \mu \mathrm{m}$ in diameter, which is equivalent to development in the human hepatoma line HepG2. These schizonts seem to develop normally in vitro; however, they fail to reach the stage at which rupture and release of merozoites occurs. The fragile nature of these cells and their failure to support complete development of liver merozoites led us to attempt to develop continuous cell lines that could be used in these experiments, and to produce a means by which to measure development of the parasites in cultivation.

Two cell lines were produced that supported growth and complete development of $P$. berghei liver stages in vitro. One of these lines (mouse $X$ rat hybrid; E2) expresses surface murine class I MHC antigens, which were detected by flow cytometry (Fig. 3). Both cell lines were positive for albumin, indicating they had retained this hepatocyte-specific function. The ability of these two lines to support invasion and development of $P$. berghei sporozoites differs considerably. Approximately $0.3 \%$ of the sporozoites develop to form schizonts in the BALB/c line, whereas approximately $0.05 \%$ do so in the mouse $X$ rat line. The schizonts achieved approximately $75 \%$ of their final size by $28 \mathrm{~h}$ after infection. The DNA probe indicated that the parasite produced little or no new DNA during the first $24 \mathrm{~h}$; however, considerable new DNA was detected $40 \mathrm{~h}$ after infection. This is approximately $7 \mathrm{~h}$ before merozoite release occurs in this system $147 \mathrm{~h}$ postinfection). Merozoite release occurs at 42 to $44 \mathrm{~h}$ postinfection in vivo.

These studies demonstrate that $P$. berghei EE stages can be cultured successfully in primary murine hepatocytes and in continuous mouse cell lines. The EE stages develop morphologically to a mature schizont stage and, in the case of the continuous lines, proceed further to rupture and release infectious merozoites. Such systems should prove to be of great importance for studying the interaction between immune $\mathrm{T}$-lymphocytes and the liver stages of $P$. berghei.

\section{REFERENCES}

1. Chen, D. H.; Tigelaar, R. E.; Weinbaum, F. I. Immunity to sporozoite induced malaria infection in mice. $\mathrm{I}$. The effect of immunization on $\mathbf{T}$ and $\mathbf{B}$ cell deficient mice. J. Immunol. 188:1322-1327; 1977.

2. Egan, J. E.; Weber, J. L.; Ballou, R., at al. Efficacy of murine malaria sporozoite vaccines: implications for human vaccine development. Science 236:453-456; 1987.

3. Foley, D. A.; Kennard, J.; Vanderberg, J. P. Plasmodium berghei: infective exoerythrocytic schizonts in primary monolayer cultures of rat liver cells. Ex. Parasitol. 46:166-178; 1978.

4. Hoffman, S. L.; Berzofsky, J. A.; Isenbarger, D., et al. Immune response gene regulation of immunity to Plasmodium berghei sporozoites and circumsporozoite protein vaccines: overcoming 
genetic restriction with whole organism and subunit vaccines. $J$. Immunol. 142:3581-3584: 1989.

5. Hollingdale, M. R.; Leef, J. L.; McCullough. M., et al. In titro cultivation of the exoerythrocytic stage of Plasmodium berghei from sporozoites. Science 213:1021-1022: 1981.

6. Hollingdale, M. R.; Leland, P. Detection of exoerythroeytic stages of Plasmodium berghei in fixed liver tissue and cultured cells by an immunoperoxidase antibody technique. Trans. $R$. Soc. Trop. Med. Hyg. 76:624-626; 1982.

`. Hollingdale, M. R.: Leland, P.; Leef. J. L.. et al. Entry of Plasmodium berghei sporozoites into cultured cells and their transformation into trophozoites. Am. J. Trop. Med. Hyg. $32: 685-690 ; 1983$

8. Hollingdale, M. R.; Zavala, F.: Nussenzweig, R. S., et al. Antibodies to the protective antigen of Plasmodium berghei sporozoites prevent entry into cultured cells. J. Immunol. 128:1929-1930; 1982.

9. Klaunig, J. E.; Goldblatt, P. J.; Hinton, D. E.. et al. Mouse liver cell culture. I. Hepatocyte isolation. In Vitro 17:913-925; 1981.

10. Levitt. D.; King, M. Methanol fixation permits flow cytometric analysis of immunofluorescent stained intracellular antigens. J. Immunol. Methods 96:233-237; 1987.

11. Nussenzweig. R. S.; Vanderberg. J.; Most. H. Specificity of protective immunity produced by $\mathrm{x}$-irradiated Plasmodium berghei sporozoites. Nature 222:488-489; 1969.
12. Vussenzweig. R. S.; Vanderberg. J.: Most, H., et al. Protective immunity produced by the injection of $\mathrm{x}$-irradiated sporozoites of Plasmodium berghei. Nature 216:160-162;196\%.

13. Ozato. K.; Mayer, N. M.: Sachs. D. H. Monoclonal antibodies to mouse major histocompatability complex antigens. IV. A series of hybridoma clones producing anti-H-2d antibodies and an examination of expression of $\mathrm{H}-2^{d}$ antigens on the surface of these cells. Transplantation 34:113-119: 1982.

14. Pirson. P. Culture of the exoerythrocytic liver stages of Plasmodium berghei sporozoites in rat hepatocytes. 'Trans. R. Soc. Trop. Med. Hyg. i6:422; 1982.

1.5. Schofield. L.: Villaquiran. J.: Ferreira. A.. et al. Gamma interferon. $\mathrm{CI} 88^{\star} \mathrm{T}$ cells and antibodies required for immunity to malaria sporozoites. Nature 330:664-666; 198 .

16. Srhuman. B.: Hunter. K. W. Secretion of acetylcholinesterase by a monse hepatocyte $X$ rat liver cell hybrid culture. In Vitro $22: 6 \div 0-6 \div 6 ; 1986$.

17. Stallcup. K. C.: Springer, 'T. A.: Mescher, M. F. Characterization of an anti-HI-2 monoclonal antibody and its use in large scale purification. J. Immunol. 12 i:923-930: 1981.

18. Weiss. W. R.; Sedegah. M.; Beaudoin. R. L.., et al. CD8*T cells teytotoxic/suppressors) are required for protection in mice immunized with malaria sporozoites. Proc. Natl. Acad. Sci. LSA 85:573-5:6; 1988.

This work was supported by the Naval Medical Research and Development Command, Bethesda, MD, work unit no. 3M161102B510AK111, ONR contract N00014-83-C-035j, and by contract DPE-0453-C-003051-00 of the U.S. Agency for International Development. Washington, D.C.

The opinions and assertions herein are not to be construed as official or as reflecting the views of the Navy Deparment or the naval service at large. The experiments reported herein were conducted according to the principles set forth in the current edition of the "Guide for the Care and Use of Laboratory Animals". Institute of Laboratory Animal Resources, National Research Council, DHHS, Pub. no. (NIH)85-23.

We thank Neil Hardegen for the FACs analysis.

\section{Book Review}

\section{Benchmarks: Alternative Methods in Toxicology \\ M. A. Mehlman, Editor \\ Princeton Scientific Publishing Co.. Inc.: 1989}

Workers in the area of Toxicology have for some years recognized two basic conditions; descriptive Toxicology, as embodied by the $\mathrm{LD}_{\text {so }}$ and the Draize test, is no longer a scientifically viable area or vehicle for study, and the cost of statutorily mandated toxicity and carcinogenicity testing has become extraordinary (estimated to be about $\$ 1,000,000 /$ test chemical). Compound these factors with the public demand for humane treatment of laboratory animals. reduction of the number of animals used, and the need to reduce the expense and time delay involved with standard animal testing protecols, then the need for development of alternative methods in Toxicology is clear. This volume, Benchmarks: Alternative Methods in Toxicology, the first in a series, presents review articles on technical aspects of the topic of alternatives to animal testing in Toxicology. The editor, Dr. Myron A. Mehlman, has assembled contributions from recognized experts in the major topics in alternative testing. The nine technical chapters in the book address the areas of statistical and computer analysis and modeling of test results; pharmicokinetic modeling; structure activity relationships; and in vitro testing methodologies for genotoxicity, teratogenesis and carcinogenesis including bacterial and tissue culture methods. Methods and potential uses are evaluated realistically and practically, without suggestion that in the forseeable future animal testing can be completely abandonded. The chapters are not intended to be methodological summaries in the sense of an application manuals, although the references are complete and provide an excellent compendium of the current literature in these topics. The greatest value of this book is that all of the newest alternatives in the testing area are described in a single location.

The tenth chapter is contributed by representatives of the animal right movement. Animal use in science has not been historically characterized by rational discussion of balancing the public health necessity of research and testing with the need to treat animals humanely and with respect for their status as sentient individuals. Although there is no clear moral high ground in this issue, participation by these representatives recognizes that the scientific community is trying to address question of humane and efficient use of animals to promote public safety.

Benchmarks: Alternative Methods in Toxicology provides a worthwhile summary of the current efforts to develop accurate, dependable and predictive method for toxicity testing with minimal use of animals.

Michael J. Meredith, Ph.D. Department of Biochemistry School of Dentistry, Oregon Health Sciences University, 611 S.W. Campus Drive, Portland, Oregon 97201. 